\title{
Extracellular Xylanase Production by Fusarium species in Solid State Fermentation
}

\author{
MOHAMMED IMAD EDDIN ARABI, YASSER BAKRI* and MOHAMMED JAWHAR \\ Department of Molecular Biology and Biotechnology, Damascus, Syria \\ Received 4 May 2011, revised 11 July 2011, accepted 15 July 2011
}

\begin{abstract}
Fusarium sp. has been shown to be a promising organism for enhanced production of xylanases. In the present study, xylanase production by 21 Fusarium sp. isolates (8 Fusarium culmorum, 4 Fusarium solani, 6 Fusarium verticillioides and 3 Fusarium equiseti) was evaluated under solid state fermentation (SSF). The fungal isolate Fusarium solani SYRN7 was the best xylanase producer among the tested isolates. The effects of some agriculture wastes (like wheat straw, wheat bran, beet pulp and cotton seed cake) and incubation period on xylanase production by F. solani were optimized. High xylanase production $(1465.8 \mathrm{U} / \mathrm{g})$ was observed in wheat bran after $96 \mathrm{~h}$ of incubation. Optimum $\mathrm{pH}$ and temperature for xylanase activity were found to be 5 and $50^{\circ} \mathrm{C}$, respectively.
\end{abstract}

Ke y w ord s: Fusarium sp., solid-state fermentation, xylanase

\section{Introduction}

To date xylanase has gained increasing attention because of its various biotechnological applications. Endo- $\beta$-1, 4-xylanase plays important roles in animal feed, increasing the body weight gains of animals (Medel, et al., 2002). In pulp and paper industry, xylanases are employed in the prebleaching process to reduce the use of toxic chlorine chemicals (Wong et al., 2002). In bread and bakery industry, xylanases are used to increase dough viscosity, bread volume, and shelf life (Romanowska et al., 2003). Other potential applications include the conversion of xylan in wastes from agriculture and food industries into xylose, and the production of fuel and chemical feedstocks (Sunna and Antranikian, 1997). Xylanolytic enzymes are produced by a wide variety of microorganisms, among which the filamentous fungi are especially interesting as they secrete these enzymes into the medium and their xylanase activities are much higher than those found in yeast and bacteria (Haltrich et al., 1996; Khan et al., 2003; Guimaraes et al., 2006). However, to reach commercial feasibility, enzyme production must be increased by introducing a more potent strain and by optimizing culture conditions.

Fusarium is a large genus of filamentous fungi, and most Fusarium species are harmless saprobes and relatively abundant members of the soil microbial community (Domsch et al., 1980; Nwanma et al., 1993). This ecological habitat of the fungus implies that Fusarium would be a useful resource of extracellular enzymes.
However, information on the ability of xylanase production in Fusarium spp. is rarely reported.

Among the processes used for xylanase production, solid state fermentation (SSF) is an attractive one because its presents many advantages, especially for fungal cultivations (Weiland, 1988; Bakri et al., 2003; Arabi et al., 2001).

In SSF, the productivity per reactor volume is much higher compared to that of submerged culture (Haltrich et al., 1996). Also, the operation cost is lower, because simple plant, machinery and energy are required (Poorna and Prema 2007). Many SSF processes for enzyme production, including xylanase, are described in the literature (Pandey, 1994).

The objectives of the present study were (i) to investigate, on artificial growth media, the xylanase production by Fusarium sp. Isolates collected from different regions of Syria, and (ii) study the effects of some agricultural wastes on xylanase production by the promising F. solani SYRN7 isolate under SSF.

\section{Experimental}

\section{Materials and Methods}

Fungal isolates. Over several years, more than 105 isolates of Fusarium spp. were obtained from wheat seeds showing disease symptoms in different locations of Syria. Seeds were sterilized in 5\% sodium hypochlorite $(\mathrm{NaOCl})$ for $5 \mathrm{~min}$. After three washings with sterile

* Corresponding author: Y. Bakri, Department of Molecular Biology and Biotechnology, AECS, P.O. Box 6091, Damascus, Syria; e-mail: ascientific@aec.org.sy 
distilled water, the seeds were transferred onto Petri dishes containing potato dextrose agar (PDA, DIFCO, Detroit, MI. USA) with $13 \mathrm{mg} / \mathrm{l}$ kanamycin sulphate added after autoclaving and incubated for 10 days, at $23 \pm 1^{\circ} \mathrm{C}$ in the dark to allow mycelial growth and sporulation. All isolates were identified morphologically according to Nelson et al. (1983). In previous studies, different wheat genotypes had been inoculated with 105 fungal isolates, evaluating host-pathogen reactions using the method described by Kiprop et al. (2002). Emphasis was placed on selecting isolates that induced differential reactions on specific genotypes (Alazem, 2007), leading to selection of the 21 monosporic isolates (eight belonging to F. culmorum, four to F. solani, six to F. verticillioides and three to F. equiseti) used in this study. The Fusarium isolates, their host plants, and geographic origin are listed in Table I. The cultures were maintained on silica gel at $4^{\circ} \mathrm{C}$ until needed.

Xylanase production medium. Enzyme production by the selected isolates was carried out in $250 \mathrm{ml}$ Erlenmeyer flasks containing $5 \mathrm{~g}$ of solid substrate and nutrients (based on $100 \mathrm{ml}$ of liquid medium) plus distilled water to adjust the moisture content to $75 \%$. The fermentation medium consisted of: $(\mathrm{g} / \mathrm{L}) \mathrm{Na}_{2} \mathrm{HPO}_{4} \times 2 \mathrm{H}_{2} \mathrm{O} 10$; $\mathrm{KCl} 0.5 ; \mathrm{MgSO}_{4} \times 7 \mathrm{H}_{2} \mathrm{O} 0.15$, and Yeast extract 5 , as a nitrogen source. The influences of different lignocellulosic materials (wheat bran, beet pulp and cotton seed cake) on xylanase production were tested. Fresh fungal spores have been used as inoculums and $1 \mathrm{~mL}$ spore suspension (containing around $10^{6}$ spores $/ \mathrm{mL}$ ) was added to sterilized medium and incubated at $30^{\circ} \mathrm{C}$. The flasks were removed after cultivation and the enzyme was extracted by adding distilled water containing $0.1 \%$ Triton $\times 100$ to make the volume in a flask $100 \mathrm{~mL}$. The flasks' contents were stirred for 1.5 hours on a magnetic stirrer. The clear supernatant was obtained by centrifugation $(5000 \times \mathrm{g}$ for $15 \mathrm{~min})$ followed by filtration (Whatman no 1 paper).

Enzyme assay. Xylanase activity was assayed by the optimized method described by Bailey et al. (1992), using $1 \%$ birchwood xylan as substrate. The solution of xylan and the enzyme at appropriate dilution were incubated at $55^{\circ} \mathrm{C}$ for 5 minutes and the reducing sugars were determined by the dinitrosalicylic acid procedure (Miller, 1959), with xylose as standard. The released xylose was measured spectrophotometrically at $540 \mathrm{~nm}$. One unit (U) of enzyme activity is defined as the amount of enzyme releasing $1 \mu \mathrm{mol}$ xylose $/ \mathrm{ml}$ per minute under the described assay conditions.

Effect of temperature and $\mathrm{pH}$ on enzyme activity. To determine temperature activity profile for xylanase enzyme, assay was carried out at several temperatures $40,45,50,55,60,65,70$, and $75^{\circ} \mathrm{C}$ at $\mathrm{pH}$. The optimum $\mathrm{pH}$ was determined by measuring the activity at $50^{\circ} \mathrm{C}$ using the following buffers: $0.1 \mathrm{M}$ Citrate-
Table I

Fusarium isolates, host, location and extracellular xylanse production in solid state fermentation after 5 days of incubation at $30^{\circ} \mathrm{C}$

\begin{tabular}{|c|c|c|c|c|}
\hline Isolate & Host & Location & $\begin{array}{c}\text { Year of } \\
\text { collection }\end{array}$ & $\begin{array}{c}\text { Xylanase } \\
(\mathrm{U} / \mathrm{g})\end{array}$ \\
\hline \multicolumn{5}{|c|}{ F. culmorum } \\
\hline SY1 & wheat seeds & north-west & 2005 & 20.3 \\
\hline 2 & wheat seeds & north-west & 2005 & 96.36 \\
\hline 3 & wheat seeds & north-west & 2005 & 163.69 \\
\hline 4 & wheat seeds & north-west & 2005 & 12.16 \\
\hline 6 & wheat seeds & north-west & 2005 & 131.93 \\
\hline 12 & wheat seeds & north-west & 2005 & 115.92 \\
\hline 13 & wheat seeds & north-west & 2004 & 90.64 \\
\hline 14 & wheat seeds & middle region & 2003 & 19.52 \\
\hline \multicolumn{5}{|c|}{ F. verticillioides } \\
\hline SY9 & wheat seeds & north-west & 2005 & 138.72 \\
\hline 10 & wheat seeds & north-west & 2005 & 19.52 \\
\hline 15 & wheat seeds & north-west & 2004 & 61.92 \\
\hline 17 & wheat seeds & middle region & 2005 & 16.56 \\
\hline 18 & wheat seeds & middle region & 2005 & 129.92 \\
\hline 19 & wheat seeds & middle region & 2004 & 108.56 \\
\hline 21 & wheat seeds & middle region & 2003 & 102.3 \\
\hline \multicolumn{5}{|c|}{ F. solani } \\
\hline SY7 & wheat root & middle region & 2003 & 908.2 \\
\hline 8 & wheat seeds & north-west & 2004 & 125.6 \\
\hline 11 & wheat root & north-west & 2005 & 112.16 \\
\hline 20 & wheat root & north-west & 2004 & 234.96 \\
\hline \multicolumn{5}{|c|}{ F. equiseti } \\
\hline SY22 & wheat seeds & north-west & 2005 & 93.2 \\
\hline 23 & wheat seeds & north-west & 2003 & 84.64 \\
\hline 24 & wheat seeds & middle region & 2005 & 122.43 \\
\hline \multicolumn{5}{|c|}{ LSD 5\% } \\
\hline
\end{tabular}

LSD: Least Significant Difference at $\mathrm{P}<0.05$

phosphate ( $\mathrm{pH} 4.0-6.0) ; 0.1 \mathrm{M}$ potassium-phosphate (pH 7.0-8.0) and 0.1M Tris- $\mathrm{HCl}$ (pH 9.0).

Statistical analysis. The experiments were repeated twice. Results were subjected to an analysis of variance (Anon., 1996) using the super ANOVA computer package to test for differences in xylanase production among isolates.

\section{Results and Discussion}

Table I shows that all the Fusarium species were capable of producing xylanase activity but to varying degrees (Table I). Significant differences $(P<0.05)$ in the mean yield values were detected among isolates, with high values being consistently higher in the isolates F. solani SYRN7 and SYRN20 with mean value 908.2 U/g and $234.69 \mathrm{U} / \mathrm{g}$, respectively. Low enzyme activities of 12.16 and $16.56 \mathrm{U} / \mathrm{g}$ were detected for F.culmorum SYRN4 and F. verticillioides SYRN17, 


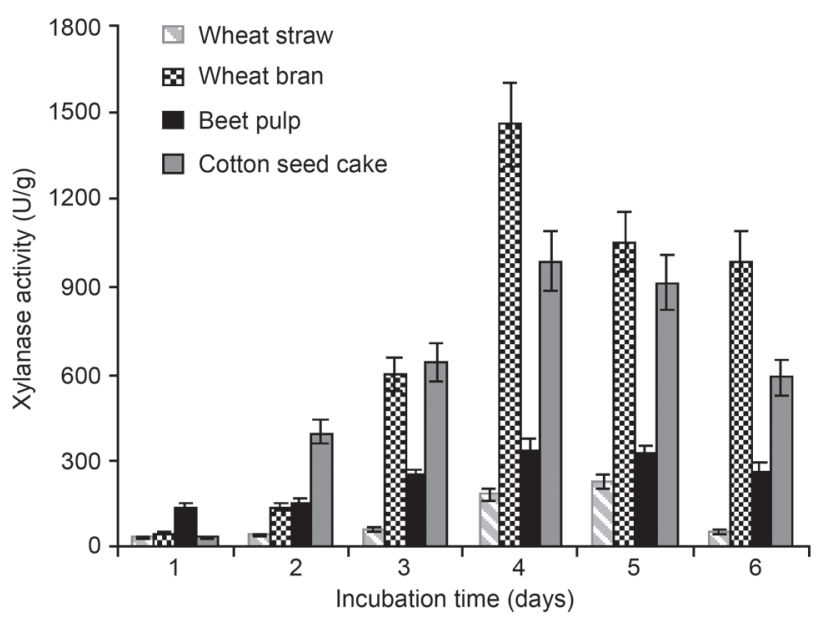

Fig. 1. The effect of lignocellulosic materials (wheat straw, wheat bran, beet pulp, and cotton seed cake) on xylanase production by Fusarium solani F7.

respectively (Table I). From this group, F.solani SYRN7 isolate was selected for further studies. This isolate was isolated from infected wheat seeds showing disease symptoms, and screened among 105 isolates as the best xylanase producer in SSF culture. The isolate was grown on PDA medium and identified as described above.

Since the cost of the substrate plays a crucial role in the economics of xylanase production process, the expensive substrate (pure xylan) is not suited for larger-scale production processes due to its high cost. Insoluble lignocellulosic materials offer a cost effective substrate for xylanaase production (Bakri et al., 2003; Li et al., 2007). To select a suitable carbon source and incubation time for xylanase production, Fusarium solani SYRN7 was cultivated in a basal medium containing some lignocellulosic materials wheat straw, wheat bran, beet pulp and cotton seed cake as carbon sources during 6 days. We observed that maximum enzyme activity $(1465 \mathrm{U} / \mathrm{g})$ was obtained by using wheat bran after 4 days of incubation (Fig. 1). This indicated that the choice of an appropriate substrate is of great importance for the successful xylanase production. The substrate not only serves as a carbon and energy source, but also provides the necessary inducing compounds for the organism. Wheat bran proved to be the best carbon source followed by cotton seed cake. In some fungi, high xylanase production has been shown to be linked strictly to the ratio of cellulose to xylan of the growth substrate and substrate degradation due to time course or incubation period (Haltrich et al., 1996; Chirstakopoullos et al., 1999; Kang et al., 2004).

Enzyme activity is markedly affected by $\mathrm{pH}$. This is because substrate binding and catalysis are often dependent on charge distribution on both substrate and, in particular, enzyme molecules (Kulkarni et al., 1999). A pH range from 4 to 10 was used to study the effect of $\mathrm{pH}$ on xylanase activity and the results are given in Fig. 2. The favorable $\mathrm{pH}$ range for xylanase activity of Fusarium solani SYRN7 was between 5.0 and 6.0, with optimum $\mathrm{pH}$ at 5.0. A significant drop in enzyme activity was observed below pH 5.0 and above $\mathrm{pH}$ 6.0. A sharp decrease of xylanase activity was observed between pH 5.0 (100\%) and pH 8.0 (47.16\%). The enzyme behaviour clearly indicates that it is more suitable for any application in the $\mathrm{pH}$ range of 5.0-6.0. Similar results were observed for other microorganisms. Aspergillus sp. (Khanna etal., 1995), A.oryzae (Kitamoto et al., 1999), Fusarium verticillioides (Saha, 2003), Penicillium citrinum (Tanaka et al., 2005) and Penicillium sp. AH-30 (Li et al., 2007), presented xylanase with maximum activities at similar $\mathrm{pH}$.

The effect of temperature on the xylanase activity from Fusarium solani SYRN7 is shown in Fig. 3. The

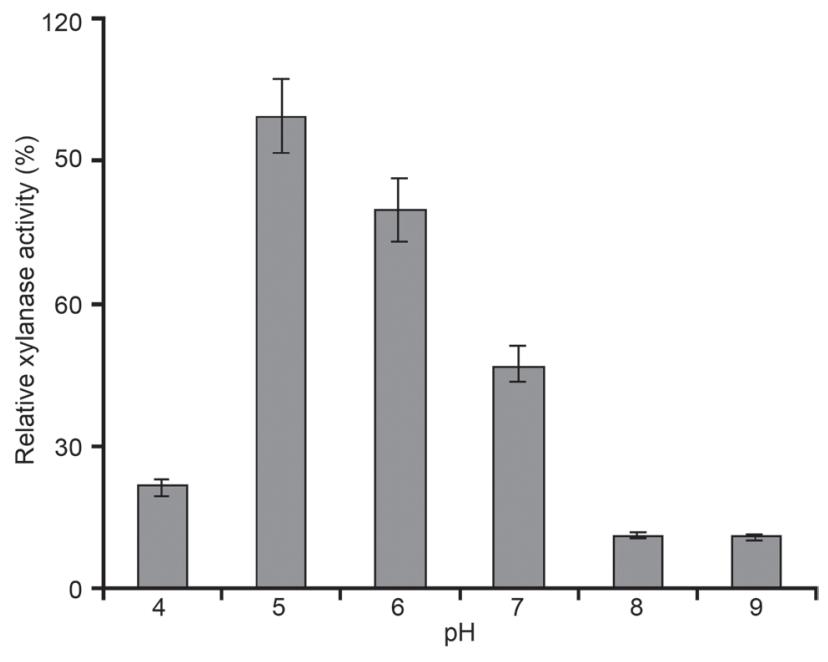

Fig. 2. Optimum $\mathrm{pH}$ activity of xylanase produced by Fusarium solani F7 grown on wheat bran under solid state culture. Relative activity was determined at $55^{\circ} \mathrm{C}$.

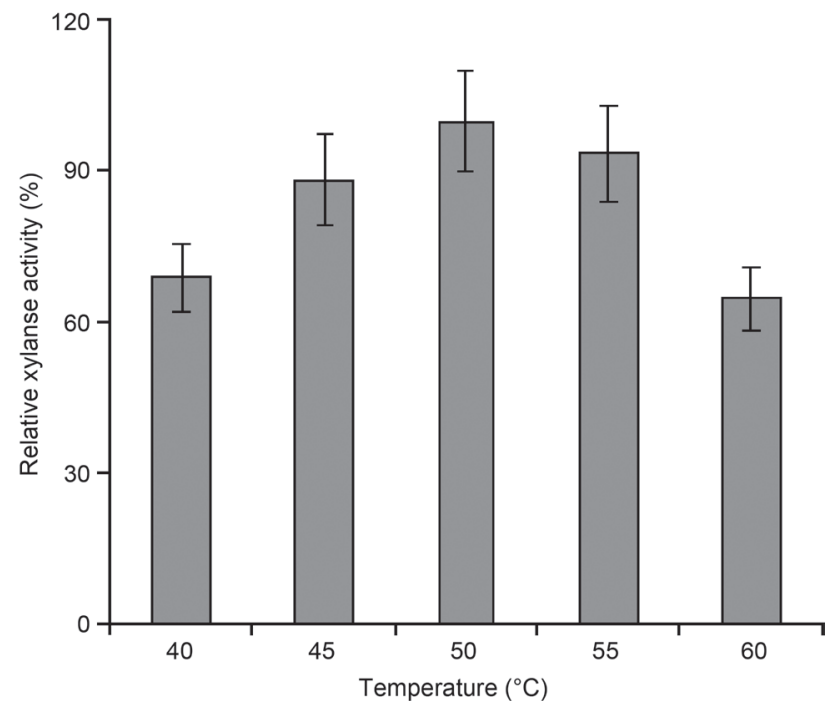

Fig. 3. Optimal temperature of xylanase produced by Fusarium solani F7 in solid state culture.

Relative activity was determined at $\mathrm{pH} 5$. 
optimum temperature was $50^{\circ} \mathrm{C}$. When the temperature reached $60^{\circ} \mathrm{C}$, relative xylanase activity retained was about $64.75 \%$ under the assay conditions used. The optimum temperature for xylanases from fungal sources has been found to be similar or slightly higher. Penicillium citrinum (Tanaka et al., 2005), Penicillium sp. AH-30 (Li et al., 2007), Aspergillus sydowii SBS 45 (Nair et al., 2008) and Aspergillus niveus RS2 (Sudan and Bajaj, 2007) presented xylanase with maximum activities at $50^{\circ} \mathrm{C}$. Penicillium purpurogenum (Belancic et al., 1995), Aspergillus orysae (Kitamoto et al., 1999) and Aspergillus niger (Coral et al., 2002) presented xylanase with maximum activities at $60^{\circ} \mathrm{C}$.

The present study demonstrated that significant improvement of xylanase production by F. solani SYRN7 isolate could be obtained by selective use of nutrients and growth conditions. Since xylan is an expensive substrate for commercial scale xylanase production, the possibility of using wheat bran for xylanase production was investigated. Wheat bran ( $5 \%$ by mass per volume) could be used as a less expensive substrate for efficient xylanase production $(1465.8 \mathrm{U} / \mathrm{g})$. This observation is interesting due to the low cost of this carbon source. The F. solani SYRN7 isolate proved to be a promising microorganism for xylanase production.

\section{Acknowledgements}

The authors thank the Director General of AECS and the Head of the Molecular Biology and Biotechnology Department for their continuous support throughout this work. Thanks also extended to Dr. A. Aldaoude for critical reading of the manuscript.

\section{Literature}

Alazem M. 2007. Characterization of Syrian Fusarium species by cultural characteristics and aggressiveness. Thesis, University of Damascus, Faculty of Agriculture. pp. 72.

Anon. 1996. Statview 4.5. USA: Abacus Concepts Corporation.

Arabi M.I.E., M. Jawhar and Y. Bakri. 2001. Effect of additional carbon sources and moisture level on xylanase production by Cochliobolus sativus in solid fermentation. Microbiology 80: 1-4.

Bailey M.J., P. Baily and R. Poutanen. 1992. Interlaboratory testing of methods for assay of xylanase activity. J. Biotechnol. 23: 257-270. Bakri Y., P. Jacques and P. Thonart. 2003. Xylanase production by Penicillium canescens $10-10 \mathrm{c}$ in solid-state fermentation. Appl. Biochem. Biotech. 108: 737-748.

Belancic A., J. Scarpa, A. Peirano, R. Diaz, J. Steiner and J. Eyzaguirre. 1995. Penicillium purpurogenum produces several xylanase: Purification and properties of two of the enzymes. J. Biotechnol. 41: 71-79.

Chirstakopoullos P., D. Mamma, W. Nerinckxw, D. Kekos and B. Macris. 1999. Production and partial characterization of xylanase from Fusarium oxysporum. Bioresour. Technol. 58: 115-119.

Coral G., B. Arikan, M.N. Ünaldi and H. Korkmaz-Güvenmez. 2002. Some properties of thermostable xylanase from an Aspergillus niger strain. Ann. Microbiol. 52: 299-306.

Domsch K.H., W. Gams and T. H. Anderson. 1980. Compendium of soil fungi. Academic Press, London.

Guimaraes L.H.S., P.S. Nogueira, M. Michelin, A.C.S. Rizzatti, V.C. Sandrim, F.F. Zanoela, A.C.M.M. Aquino, A.B. Junior and M.L.T.M. Polizeli. 2006. Screening of filamentous fungi for produc- tion of enzymes of biotechnological interest. Brazil. J. Microbiol. 37: 474-480.

Haltrich D., B. Nidetzky, K.D. Kulbe, W. Steiner and S. Zupaneie. 1996. Production of fungal xylanases. Biores. Technol. 58: 137-161. Kang S.W., Y.S. Park, J.S. Lee, S.I. Hong and S.W. Kim. 2004. Production of cellulose and hemicellulases by Aspergillus niger KK2 from lignocellulosic biomass. Bioresour. Technol. 91: 153-156.

Kiprop E. K., J.P. Baudoin, A.W. Mwangómbe, P.M. Kimani, G. Mergeai and A. Maquet. 2002. Characterization of Kenyan isolates of Fusarium udum from Pigeonpea [Cajanus cajan (L.) Millsp.] by cultural characteristics, aggressiveness and AFLP analysis. J. Phytopathol. 150: 517-527.

Kitamoto N., S. Yoshino, K. Ohmiya and N. Tsukagoshi. 1999. Purification and characterization of overexpressed Aspergillus oryzae xylanase XynF1. Biosc. Biotechnol. Biochem. 63: 1791-1794. Khan A., I. Ul-Haq, W.A. Butt and Ali S. 2003. Isolation and screening of Aspergillus isolates for xylanase biosynthesis. Biotech. 2: 185-190.

Khanna P., S.S. Sundari and N.J Kumar. 1995. Production, isolation and partial purification of xylanase from an Aspergillus sp. World J. Microbiol. Biotechnol. 11: 242-243.

Kulkarni N., A. Shendye and M. Rao. 1999. Molecular and biotechnological aspects of xylanases. FEMS Microbiol. Rev. 23: 411-456.

Li Y., Z. Liu, F. Cui and Y.X.H. Zhao. 2007. Production of xylanase from a newly isolated Penicillium sp. ZH-30. World J. Microbiol. Biotechnol. 23; 837-843.

Medel, P., F. Baucells, M.I. Gracia, C. Blas and G.G. Mateos. 2002. Processing of barley and enzyme supplementation in diets for young pigs. Animal Feed Sci. Technol. 95: 113-122.

Miller G.L. 1959. Use of dinitrosalicylic acid reagent for determination of reducing sugars. Ann. Chem. 31: 426-428.

Nair S.G., R. Sindhu and S. Shashidhar. 2008. Purification and biochemical characterization of two xylanases from Aspergillus sydowii SBS 45. Appl. Biochem. Biotechnol. 149: 229-243.

Nelson P.E., T.A. Toussoun and W.F.O. Marasas. 1983. Fusarium Species: An Illustrated Manual for Identification. The Pennsylvania State Univ. Press, University Park.

Nwanma B., N. Onyike and P. E. Nelson. 1993. The distribution of Fusarium species in soils planted to millet and sorghum in Lesotho, Nigeria and Zimbabwe. Mycopathologia 121: 105-114.

Pandey A. 1994. Solid state fermentation: an overview, In: Solid state fermentation. Ashok Pandey, Wiley Eastern, New Deli.

Poorna C.A. and P. Prema. 2007. Production of cellulose-free endoxylanase from novel alkalophilic thermotolerent Bacillus pumilus by solid-state fermentation and its application in waste paper recycling. Bioresour Technol. 98: 485-490.

Romanowska A., K.P. Janowska and S. Bielecki. 2003. The application of fungal endoxylanase in bread-making. Commun. Agric. Appl. Biol. Sci. 68: 317-320.

Saha B.C. 2003. Hemicellulose bioconversion. J. Ind. Microbiol. Biotechnol. 30: 279-291.

Sudan R. and B.K. Bajaj. 2007. Production and biochemical characterization of xylanase from an alkalitolerant novel species Aspergillus niveus RS2. World J. Microbiol. Biotechnol. 23: 491-500.

Sunna A. and G. Antranikian. 1997. Xylanolytic enzymes from fungi and bacteria. Crit. Rev. Biotechnol. 17: 39-67.

Tanaka H., N. Toshihide., H. Sachio and O. Kazuyoshi. 2005. Purification and properties of an extracellular endo-1,4- $\beta$-xylanase from Penicillium citrinum and characterization of the encoding gene. Journal of Bioscience and Bioengineering. 100: 623-630.

Weiland P. 1988. Principles of solid state fermentation. In: F. Zadrazil, P. Reiniger (Eds), Treatment of lignocellulosics with white rot fungi, Elsevier, London, pp. 64-76.

Wong K.K.Y., C.S. James and S.H. Campion. 2002. Xylanase pre and post-treatments of bleached pulps decrease absorption coefficient. J. Pulp pap. Sci. 26: 377-383. 